\title{
THE EFFECTS OF NITROUS OXIDE UPON SENSORY THRESHOLDS
}

\author{
B. Delisle Burns, J. G. Robson, and I'. J. L. Welt
}

In THE PRECEDING PAPER (1), we have shown that nitrous oxide distorts the subjective passage of time in human subjects and in cats. Subjects breathing 20 per cent $\mathrm{N}_{2} \mathrm{O}$ in oxygen provided estimates of $15 \mathrm{sec}$. periods approximately twice as great as those they provided when breathing air. This observation made us interested in the physiological mechanism responsible for the subjective estimation of $15 \mathrm{sec}$. periods.

There is a large literature on subjective time estimation (2) and various possible mechanisms have been proposed. For instance, Hoagland (3) suggested that estimates of the passage of rtime were dependent upon the speed of the slowest of a series of chemical reactions underlying neurophysiological events. 'He was able to show that subjective estimates of time changed with change of body temperature.

It is impossible in the present state of neurophysiological knowledge to specify the neural events responsible for time estimation. One could, for instance, postulate that estimation of time depends upon the rate of decay of some relatively enduring central change which is maximal at time zero. Thus, if the instruction "estimate 15 seconds from now," caused some change in the central nervous system which decayed progressively with the passage of time, one ninght suppose that the response of the subject was triggered when the initial change had decayed to a particular and learned value. Our results (1) might therefore be explained by assuming that nitrous oxide reduces the speed of decay. There is some evidence that changes produced in the central nervous systems of subjects breathing nitrous oxide decay less rapidly than usual. Thus Summerfield and Steinbery ( 1 ) have shown that human subjects who have learned nonsense syllables forget them less rapidly when breathing nitrous oxide than they do when breathing air.

Alternatively, the subjective estination of time might depend upon an integration of a number of remembered events. Thus a subject asked to estimate a $15 \mathrm{sec}$. interval would complete this period when a learned number of remembered sensory events had accumulated. In support of this hypothesis is the accepted view that time appears to pass more rapidly for subjects in changing environments $(2,5)$. This concept of time estimation would imply that nitrous oxide produces an increase in subjective time estimates by affecting a reduction in the rate of accumulation of new, remembered events. Summerfield and Steinberg have, in fact, also shown that the number of nonsense syllables which can be learned in unit time is reduced by inhalation of nitrous oxide. This effect of

${ }^{1}$ Department of Phy'siology and the Vellcome Research Department of Anaesthesia, McGill Iniversity, Montreal. 
nitrous oxide in reducing the number of enduring responses to a series of standard external stimuli might be due to one of two mechanisms. There is evidence that nitrous oxide locks recently learned events into the central nervous system (4); thus, we could suppose that new information was hard to acquire in the presence of nitrous oxide because it was in competition with old information for the same storage mechanism. That such competition for the storage mechanism can occur in normal circumstances is well established $(6)$. Alternatively one might suppose that the main effect of nitrous oxide was to interrupt some part of the pathways from sensory endings to the storage mechanism and so reduce the information available for storage. The production of anclgresıa by nitrous oxide provides an example of such an effect. Although the action of nitrous oxide upon response to pain is well established, little information is available about the effect of light general anaesthesia on other sensory modalities $(7,8)$.

For these reasons we have tested the effect of nitrous oxide upon a variety of sensory thresholds.

\section{Subjects}

METHON

Twelve subjects were used for the experiments described in this and the preceding paper (1). There were two female subjects and the ages of all subjects lay between 27 and $1 t$ years.

\section{Apparatus}

Estimation of threshold för skin pain. For this experiment $10 \mathrm{~cm}$. of $0.2 \mathrm{~mm}$. diameter platinum wire were wound around a U-shaped glass tube of $3.5 \mathrm{~mm}$. external diameter, so that only one turn of this wire made contact with the skin when the instrument was pressed upon the forearm. The wire was heated by current supplies from an A.C. source variable between zero and 6.3 volts. Thresholds were recorded in terms of voltage.

Estimation of warmth thresholds. Radiant heat was supplied from a 250-watt General Electric heat lamp supported 18 in. above the subject's hand. The current through the lamp was controlled by a "Variac" mains transformer. A cardboard screen with an aperture was clamped between the lamp and the subject's hand and restricted the radiation to a circular area of $1 \mathrm{in}$. in diameter. The stimulus was interrupted for $1 \mathrm{sec}$. in $2 \mathrm{sec}$. by closing the aperture. Thresholds were recorded as volts supplied to the filarnent.

Estimation of touch threshold. A hollow solenoid was constructed by winding 140 turns of $0.31 \mathrm{~mm}$. varnished copper wire onto a plastic bobbin $13 \mathrm{~mm}$. long with a central hole of $5.0 \mathrm{~mm}$. diameter. The mobile core was made by gluing $1 \mathrm{~cm}$. of soft iron rod to an equal length of glass rod $2.3 \mathrm{~mm}$. in diameter; the core was a loose fit to the bore of the bobbin. The instrument was applied to the skin with the axis of the bobbin in the vertical plane; the core was dropped into place so that the glass rested upon the skin. Current pulses of $1 \mathrm{sec}$. in $2 \mathrm{sec}$. were supplied to the coil, the resultant thrust of the core deforming the skin. Thresholds were recorded as volts applied to the coil. 
Estimation of thresholds of brightness discrimination. The durations of the Hashes of light from the neon bulb used to determine the thresholds of brightness discrimination were controlled by means of a Tektronix pulse generator no. 161 . Details of the procedure which we used are given in the text.

Estimation of thresholds of hearing. The output of a variable frequency sinusoidal oscillator (Krohn-Hite no. 420-A) was fed through an attenuator to a pair of rubber-cuffed earphones. Thresholds were recorded as volts supplied to the earphones.

\section{Reslits}

Effects of nitrous oxide on human sensory threshold

Skin pain. The elevation of threshold for skin pain by light general anaesthesia is well known (7). In our own experiments 20 per cent of nitrous oxide abolished the sensation of pain accompanying a pin prick sufficient to draw blood.

In order to have a more sensitive measure of pain threshold we used an electrically heated wire in contact with the skin. In any series of consecutive tests the wire was pressed onto the skin by the subject with sufficient pressure to cause blanching and held there until the steadily rising temperature became intolerable. The thresholds obtained in these experiments were expressed in terms of that voltage which, when applied to the heating element, forced the subject to remove the wire. The voltage applied to the wire was increased at a slow and constant rate. After each threshold estimation a neighbouring piece of skin was used for the next trial. Some of the results are provided in Table I.

TABLE I

ShiN Pain Thresholds (Watts)

\begin{tabular}{ccccc}
\hline Control & \multicolumn{4}{c}{$\begin{array}{c}\text { Ratio } \\
\text { of mean }\end{array}$} \\
\hline Subject & (breathing air) & $25 \% \mathrm{~N}_{2} \mathrm{O}$ in $\mathrm{O}_{2}$ & thresholds & $p$ \\
\hline 1 & $27.6 \pm 1.4(6)$ & $47.6 \pm 3.2(6)$ & 1.72 & $<.0005$ \\
2 & $231 \pm 1.1(6)$ & $45.3 \pm 1.2(6)$ & 1.96 & $<.0005$ \\
3 & $17.7 \pm 2.3(6)$ & $28.3 \pm 2.2(6)$ & 1.60 & $.005-.0005$ \\
4 & $34.1 \pm 2.8(6)$ & $51.2 \pm 3.6(5)$ & 1.50 & $.005-.0005$ \\
\hline
\end{tabular}

Columns 2 and 3 provide the mean thresholds \pm their standard errors, with the number of observations in brackets. The fifth column provides the probability that a difference between the means, as great or greater than that found, could be due to chance.

Warmth threshold. Radiant heat was supplied from a filament-bulb to a circular area of skin, $1 \mathrm{in}$. in diameter, on the back of the hand. The stimulus was interrupted so that heat was supplied for $1 \mathrm{sec}$. in $2 \mathrm{sec}$. The distance between the heat source and the hand was kept constant and the subject was unable to see any light from the lamp. The threshold for the first perception of warmth was obtained by slowly increasing the voltage applied to the filament. Thresholds were also obtained for the disappearance of perceptible warmth as the temperature of the source was reduced from a value providing an unquestionable sensation. In preliminary experiments we found, as might be expected, that the thresholds 
measured in this way were very dependent upon skin blood flow. For this reason all the thresholds that are reported below were recorded while blood flow to the forearm was temporarily arrested with a sphygmomanometer cuff. The results are reported in Table II.

TABLE II

Warmth Thresholds (Watts)

\begin{tabular}{|c|c|c|c|c|c|}
\hline Subject & $\begin{array}{l}\text { Change } \\
\text { in test } \\
\text { temperature }\end{array}$ & $\begin{array}{c}\text { Control } \\
\text { (breathing air) }\end{array}$ & $25 \% \mathrm{~N}_{2} \mathrm{O}$ in $\mathrm{O}_{2}$ & $\begin{array}{l}\text { Ratio } \\
\text { of mean } \\
\text { thresholds }\end{array}$ & $p$ \\
\hline 1 & $\begin{array}{l}\text { Increasing } \\
\text { Decreasing }\end{array}$ & $\begin{array}{llll}36 & 5 \pm 1 & 2 & (6) \\
36 & 9 \pm 2 & 2 & (6)\end{array}$ & 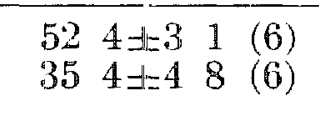 & $\begin{array}{r}144 \\
96\end{array}$ & $\begin{array}{r}<0005 \\
3-35\end{array}$ \\
\hline 2 & $\begin{array}{l}\text { Increasing } \\
\text { Decreasing }\end{array}$ & $\begin{array}{llll}41 & 6 \pm & 8 & (6) \\
50.1 \pm 3 & 1 & (6)\end{array}$ & $\begin{array}{llll}118 & 2 \pm 1 & 4 & (6) \\
130 & 3 \pm 2.2 & (6)\end{array}$ & $\begin{array}{l}2.84 \\
2.60\end{array}$ & $\begin{array}{l}<.0005 \\
<.0005\end{array}$ \\
\hline 3 & Increasing & $478 \pm 10 \quad(6)$ & $1009 \pm 35(6)$ & 2.10 & $<.0005$ \\
\hline
\end{tabular}

Columns 3 and 4 provide the mean threshold \pm heir standard errors with the number of observations in brackets; $p$ is entered as in Table 1 .

Touch threshold. Touch thresholds were measured on the lateral surface of the pulp of the little finger. Since the deformation of the skin was produced electromagnetically, thresholds for touch were measured in volts applied to the solenoid, which was energized for about $0.1 \mathrm{sec}$. at regular intervals (once in $2 \mathrm{sec}$.); an audible click occurred with each pulse. The instrument was calibrated in terms of weight applied to the skin. Subjects were asked to identify the thresholds for touch with both increasing and decreasing voltages applied to the coil. The results are summarized below in Table III.

TABLE III

Tolch Thresholds, (GM.)

\begin{tabular}{|c|c|c|c|c|c|}
\hline Subject & $\begin{array}{l}\text { Change } 11 \\
\text { stimulus } \\
\text { strength }\end{array}$ & $\begin{array}{l}\text { Control } \\
\text { (breathing air) }\end{array}$ & $25 \% \mathrm{~N}_{2} \mathrm{O}$ in $\mathrm{O}_{2}$ & $\begin{array}{l}\text { Ratio } \\
\text { of mean } \\
\text { thresholds }\end{array}$ & $p$ \\
\hline 1 & $\begin{array}{l}\text { Increasing } \\
\text { Decreasing }\end{array}$ & $\begin{array}{l}070 \pm 02(6) \\
0.54 \pm 17 \quad(6)\end{array}$ & $\begin{array}{llll}3 & 20 \pm 15 & (6) \\
2 & 75 \pm .06 & (6)\end{array}$ & $\begin{array}{l}4.57 \\
5.09\end{array}$ & $\begin{array}{l}<.0005 \\
<.0005\end{array}$ \\
\hline 2 & $\begin{array}{l}\text { Increasing } \\
\text { Decreasing }\end{array}$ & 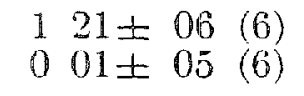 & $\begin{array}{llll}1 & 63 & 08 & (6) \\
1 & 45 \pm & 08 & (6)\end{array}$ & $\begin{array}{ll}1 & 35 \\
1 & 44\end{array}$ & $<.0005-0005$ \\
\hline$\frac{1}{1}$ & $\begin{array}{l}\text { Increasing } \\
\text { Decreasing }\end{array}$ & $\begin{array}{llll}0 & 66 \pm 06 & (6) \\
0 & 69 \pm 04 & (6)\end{array}$ & $\begin{array}{llll}1 & 14 \pm 21 \\
1 & 06 \pm 17 & (6) \\
6\end{array}$ & $\begin{array}{ll}1 & 73 \\
1 & 54\end{array}$ & $\begin{array}{l}025-05 \\
0: 25-05\end{array}$ \\
\hline
\end{tabular}

Columns 3 and 4 provide the mean thresholds \pm their standard errors with the numbers of observations in brackets; $p$ is entered as in Table $\mathbb{I}$.

Thresholds for brightness discrimination. The subjects were asked to observe, from a fixed distance, an opaque, white screen which had a constant surfaceillumination. In the centre of this screen was a circular, translucent area, $1 \mathrm{in}$. in diameter, which could be illuminated from behind; when illuminated only from the front, it appeared to be no different from the rest of the screen, but a small black spot was placed on it to allow fixation. The central translucent area could be made periodically brighter than the surround by the flashes of a neon 
bulb behind the screen. The intensity of the neon flash was constant, while its duration was variable. Thresholds of brightness discrimunation were therefore measured in milliseconds. The flashes were repeated once per 2 sec. and the duration of the flash was increased from zero until the translucent area was just perceptible. Measurements of threshold were also made by decreasing the flash duration from suprathreshold values. The results are summarized in Table IV.

It is interesting to note that the thresholds, as determined for one eye were almost twice that determined for two eyes.

TABLE IN

Thresholdos For BrightNess Discriminalion (M.SEC)

\begin{tabular}{|c|c|c|c|c|c|c|}
\hline Subject & Using & $\begin{array}{l}\text { Direction } \\
\text { of change }\end{array}$ & $\begin{array}{c}\text { Control } \\
\text { (breathing air) }\end{array}$ & $25 \% \mathrm{~N}_{2} \mathrm{O}$ in $\mathrm{O}_{2}$ & $\begin{array}{c}\text { Ratio } \\
\text { of means }\end{array}$ & $p$ \\
\hline \multirow[t]{2}{*}{1} & 2 eyes & $\begin{array}{l}\text { Increasing } \\
\text { Decreasing }\end{array}$ & 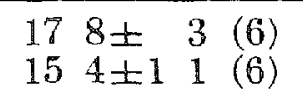 & $\begin{array}{llll}22 & 5 \pm 1 & 5 & (6) \\
19 & 7 \pm 1 & 4 & (6)\end{array}$ & $\begin{array}{ll}1 & 26 \\
1 & 28\end{array}$ & $\begin{array}{l}.005-01 \\
.01-.025\end{array}$ \\
\hline & 1 eye & $\begin{array}{l}\text { Increasing } \\
\text { Decreasing }\end{array}$ & $\begin{array}{llll}29 & 7 \pm 1 & 2 & (3) \\
31 & 2 \pm 1 & 2 & (3)\end{array}$ & $\begin{array}{lll}343 \pm & 7(3) \\
35.0 \pm 2 & 9 & (3)\end{array}$ & $\begin{array}{l}115 \\
1.12\end{array}$ & $\begin{array}{l}01-.025 \\
01-15\end{array}$ \\
\hline \multirow[t]{2}{*}{2} & 2 eyes & $\begin{array}{l}\text { Increasing } \\
\text { Decreasing }\end{array}$ & $\begin{array}{llll}16 & 0 \pm 1 & 1 & (5) \\
16 & 2 \pm & 7 & (6)\end{array}$ & $\begin{array}{llll}28 & 5 \pm 1 & 0 & (6) \\
25 & 5 \pm & 6 & (6)\end{array}$ & $\begin{array}{ll}178 \\
157\end{array}$ & $\begin{array}{l}<.0005 \\
<0005\end{array}$ \\
\hline & 1 eye & $\begin{array}{l}\text { Increasing } \\
\text { Decreasing }\end{array}$ & $\begin{array}{llll}30 & 0 \pm 1 & 5 & (3) \\
30 & 6 \pm 2 & 7 & (3)\end{array}$ & $\begin{array}{llll}46 & 3 \pm 2 & 0 & (3) \\
46 & 6 \pm 3 & 5 & (3)\end{array}$ & $\begin{array}{l}1.54 \\
1.52\end{array}$ & $<0005$ \\
\hline \multirow[t]{2}{*}{4} & 2 eyes & $\begin{array}{l}\text { Increasing } \\
\text { Decreasing }\end{array}$ & $\begin{array}{llll}17 & 8 \pm 1 & 0 & (6) \\
15 & 5 \pm 1 & 0 & (6)\end{array}$ & $\begin{array}{lll}26 & 7 \pm 1.4 & (6) \\
16 & 7 \pm 1 & 4\end{array}$ & $\begin{array}{ll}1 & 50 \\
1 & 08\end{array}$ & $\begin{aligned}< & 0005 \\
& 3-.35\end{aligned}$ \\
\hline & 1 eye & Increasing & $273 \pm \quad 8(3)$ & $387 \pm 22(3)$ & 142 & $.005-0005$ \\
\hline
\end{tabular}

Columns 4 and 5 provide the mean thresholds \pm their standard errors with the number of observations in brackets, $p$ is entered as in Table I.

Thresholds of hearing. The subjects of these tests wore earphones, through which they were presented with a 500 c.p.s. note of variable intensity. The threshold was measured as the voltage supplied to the earphones by the oscillator. Thresholds for both increasing and decreasing voltage were measured and the results appear in Table $\mathrm{V}$.

\section{TABLE $V^{\prime}$}

Thresholds OF HEARING (WATTS $\times 10^{-9}$ SUPPLIED TO EARPHONES)

\begin{tabular}{|c|c|c|c|c|c|}
\hline Subject & $\begin{array}{l}\text { Changes in } \\
\text { stimulus } \\
\text { strength }\end{array}$ & $\begin{array}{c}\text { Control } \\
\text { (breathing air) }\end{array}$ & $25 \% \mathrm{~N}_{2} \mathrm{O}$ in $\mathrm{O}_{2}$ & $\begin{array}{l}\text { Ratio of } \\
\text { mean } \\
\text { thresholds }\end{array}$ & $p$ \\
\hline 1 & $\begin{array}{l}\text { Increasing } \\
\text { Decreasing }\end{array}$ & $\begin{array}{lll}1 & 91 \pm & 26 \\
2 & 02 \pm & 24\end{array}$ & $\begin{array}{rrrr}13 & 72 \pm 2 & 33 & (6) \\
8 & 70 \pm & .91 & (6)\end{array}$ & $\begin{array}{ll}7 & 18 \\
3 & 59\end{array}$ & $\begin{array}{l}<0005 \\
<0005\end{array}$ \\
\hline 2 & $\begin{array}{l}\text { Increasing - } \\
\text { Decreasing }\end{array}$ & $\begin{array}{llll}3 & 77 \pm & 43 & (6) \\
6 & 74 \pm 1 & 46 & (6)\end{array}$ & $\begin{array}{lll}82 & 48 \pm 14.92 & (6) \\
73 & 10 \pm 12 & 20\end{array}$ & $\begin{array}{l}2190 \\
1085\end{array}$ & $\begin{array}{l}<0005 \\
<.0005\end{array}$ \\
\hline 3 & Increasing & $092 \pm 026(6)$ & $433 \pm .56(6)$ & $47 \quad 10$ & $<0005$ \\
\hline
\end{tabular}

Note: Columns 3 and 4 provide the mean thresholds $上$ their standard errors with the number of observations in brackets, $p$ is entered as in Table I. 
Effects on proprioception. We did not measure proprioceptive thresholds directly. The subject was asked to rest his arm and forearm horizontally upon a table and to fiex and extend the elbow-joint, so that his hand travelled about $15 \mathrm{~cm}$. across the table. A piece of paper was pinned to the table and the subject was instructed to move a pencil-tip between two pegs $15 \mathrm{~cm}$. apart. The subject's eyes were shut during these tests. After three trials of moving between the two pegs, one peg was withdrawn; the subject was then instructed to move the pencil from the remaining peg to the estimated position of the peg which had been removed, and mark the paper. He performed this operation ten times while breathing air and ten times under 25 per cent $\mathrm{N}_{2} \mathrm{O}$.

We were primarily interested in assessing the subject's error of proprioceptive estimation. For each trial we determined the average position of his estimate of the target distance. His error was scored as the mean deviation of his ten individual estimates (in centimetres) from this average position. Thus the second and third columns of Table VI provide the mean deviation and its standard error for our various subjects. There is some evidence from the results listed in Table VI that 25 per cent $\mathrm{N}_{2} \mathrm{O}$ produced a small increase in proprioceptive error; but for only one of our subjects was this increase statistically significant.

TABLE VI

ERRORS OF PROPRIOCEPTION (CM.)

\begin{tabular}{cccccc}
\hline Subject & Breathing air & $25 \% \times 2 \mathrm{O}$ in $\mathrm{O}_{2}$ & $\begin{array}{c}\text { Ratio of } \\
\text { mean errors }\end{array}$ & $p$ \\
\hline 1 & $81 \pm 2 \pm(10)$ & $145 \pm 31(10)$ & 179 & $05-1$ \\
2 & $124 \pm 24(10)$ & $98 \pm 35(10)$ & 380 & $25-3$ \\
3 & $30 \pm 06(10)$ & $62 \pm 16(10)$ & 207 & $025-05$ \\
4 & $236 \pm 38(10)$ & $259 \pm 48(10)$ & 110 & $35-4$ \\
\hline
\end{tabular}

No1c: For explanation of entries see tert.

We assume that any changes in true proprioceptive threshold should bear a direct relation to the proprioceptive error we have defined above.

Summary of effect of 25 per cent $\mathrm{N}_{2} \mathrm{O}$ in $\mathrm{O}_{2}$ on sensory thresholds. The results given in the tables above enable one to make a crude comparison of the vulnerability of various sensory mechanisms to 25 per cent nitrous oxide. Any such comparison must be dependent upon the units which are chosen to represent the strengths of the various stimuli used.

We have measured auditory threshold in terms of watts supplied to the earphones worn by the subject. Warmth thresholds have been estimaled in terms of watts consumed by the fikment heating lamp. Pain thresholds were determined as that point at which a bot wire became intolerable and ase given in terms of watts consumed by the wire. When measuring thresholds for brightness discrimination we varied the duration of a constant intensity source, thus our units (msec.) are proportional to quantity of light reaching the eye. Touch thresholds were estimated in grams weight distributed over a contact area of $8 \mathrm{~mm} .{ }^{2}$. Proprioceptive error was measured in terms of centimetres which are proportional to degrees of arc.

Table VII provides a comparison (taken from the data given in the other tables) of the effects of 25 per cent nitrous oxide in oxygen on the various sensory thresholds for one of our subjects. 


\section{TABLE VII}

Comparison of Effects of 25 Per Ceñt Nitrous Oxide on Sensory Thresholds in ONe Subject (No. 2)

\begin{tabular}{|c|c|c|}
\hline Sensation & $\begin{array}{l}\text { Ratio of thresholds } \\
\text { (mean threshold under } \mathrm{N}_{2} \mathrm{O} \\
\text { mean threshold in air) }\end{array}$ & Units \\
\hline Hearing & $11-22$ & Whatts supplied to earphones \\
\hline Warmth & $26-2.8$ & Watts through filament lamp \\
\hline Skin pain & 20 & Watts through heating wire \\
\hline Vision (two eyes) & $1.6-1.8$ & (Constant intensity) $\times$ (msec.) \\
\hline Touch & $1.35-1.44$ & $\mathrm{gm} . / 8 \mathrm{~nm} .^{2}$ \\
\hline $\begin{array}{l}\text { Proprioception } \\
\text { error }\end{array}$ & 80 & Degrees of arc \\
\hline
\end{tabular}

Not:: Time estimates for this subject under $\ .0$ were $1.76 \times$ (estimates while breathing air).

\section{Effects of Environment upon Subjective Time Estimation}

In the introduction to this paper, we pointed out that one mechanism by which subjects may estimate short time intervals might depend upon an-integration of sensory events recorded by the nervous system. This hypothesis implies that

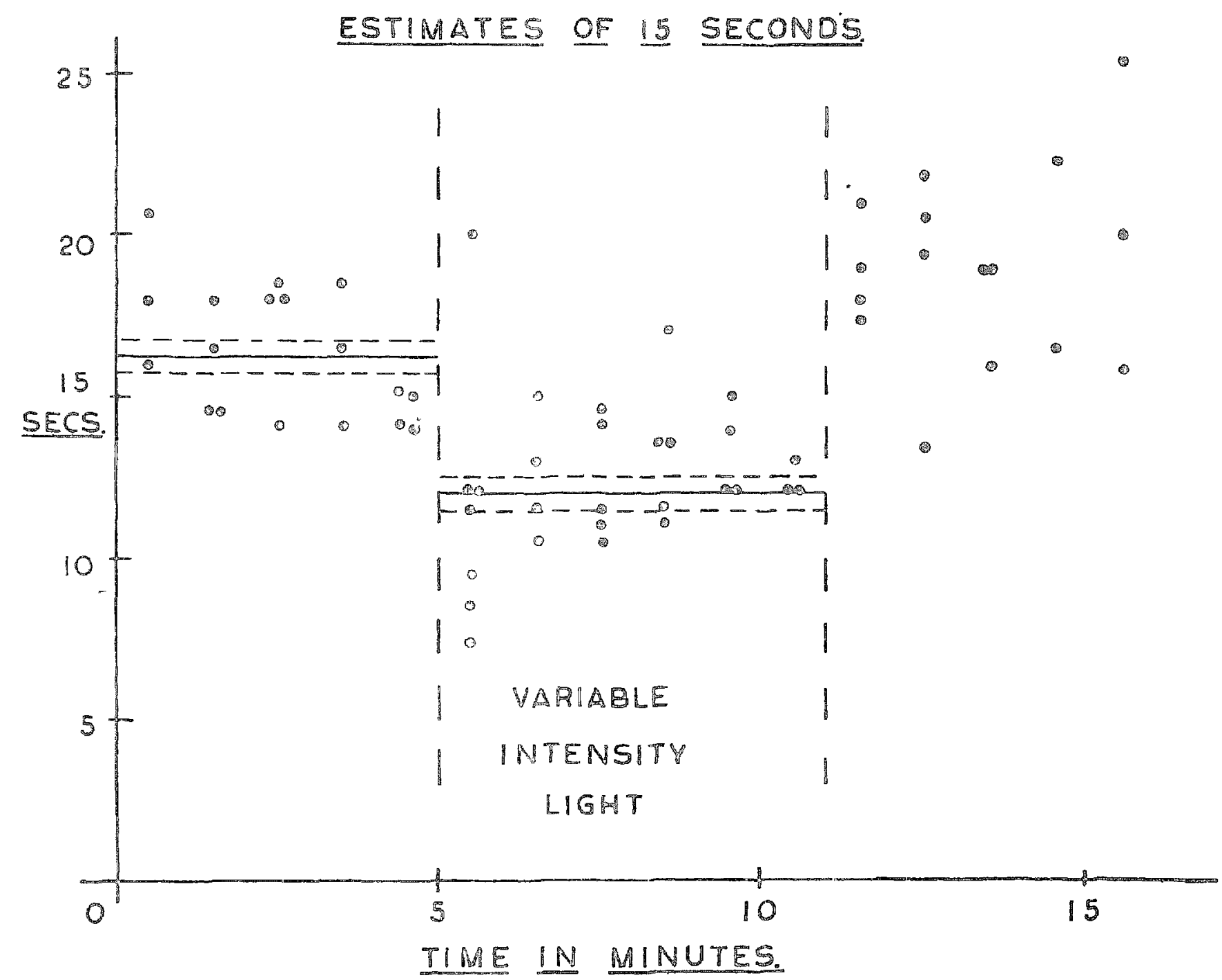

FIGLRE 1. Estimates of $15 \mathrm{scc}$. periods made by Subject 5 in relative sensory isolation. First period, control in dark and silent room; second period, during illumination of room with light of randomly varied intensity; third period, control in darkness. The mean and its standard error are indicated during the first and second periods by continuous and dotted lines respectively. 


\section{ESTIMATES OF IS SECONDS}

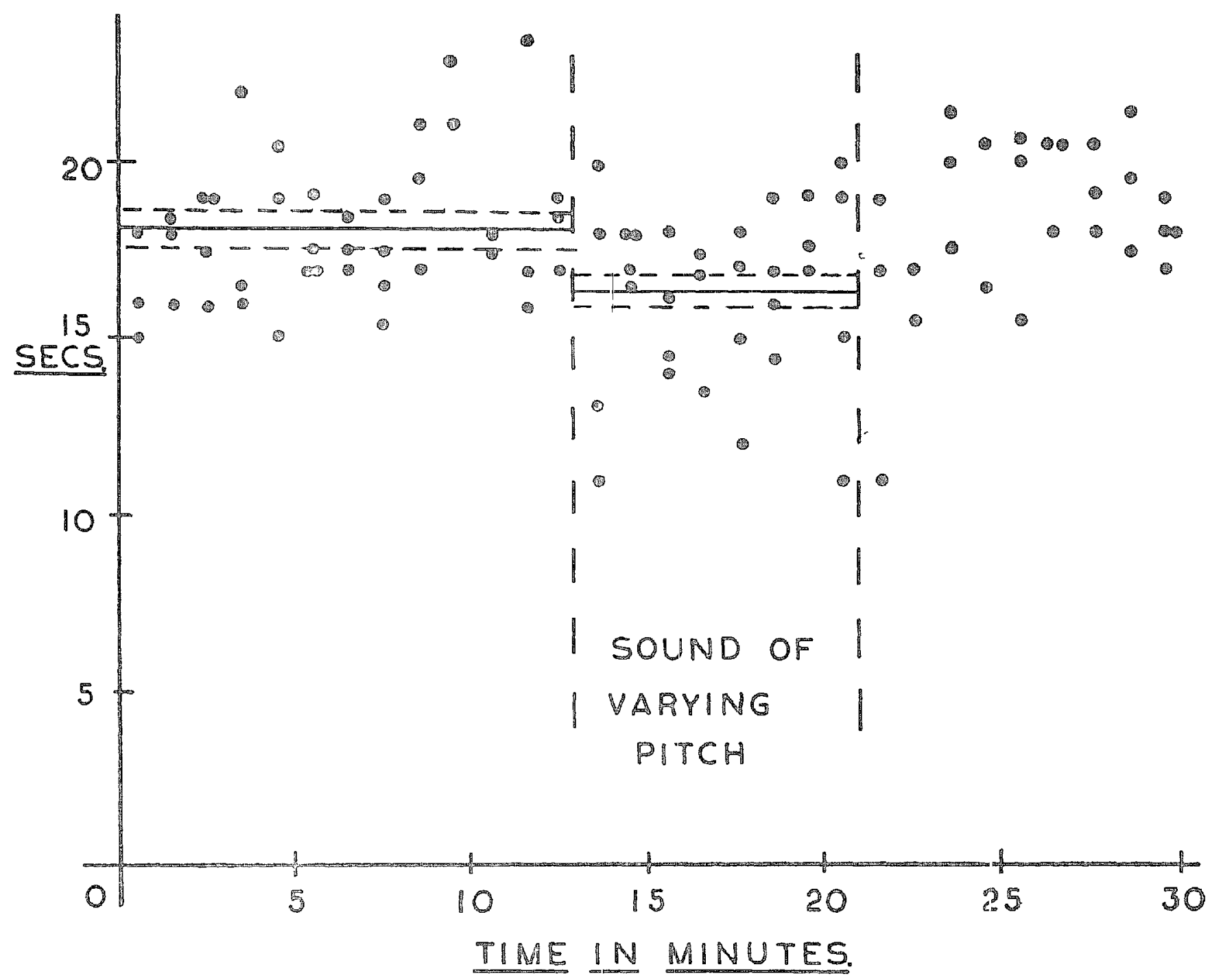

FigCRE 2. Estimates of 15 sec. periods made by Subject 1 in relative sensory isolation. First period, control in dark and silent room; second period, subject exposed to sound of randomly. varied pitch; third period, control in silence. The mean and its standard error are indicated during the first and serond periods by continuous and dotted lines respectively:

subjects breathing air should give subjective estimates of time which are longer in an environment of comparative sensory isolation than in a changing environment. There is some evidence in the literature that this is so (2) We attempted to test this prediction on subjects asked to make estimates of $1 \tilde{\mathrm{sec}}$. continuously (1) in a controlled environment. These subjects wore earphones and lay upon a bed in a quiet room which could be completely darkened. Thus we were able to test the effects of visual and auditory stimuli upon subjective estimation of time. Our results show that the addition of auditory or visual stimuli decrease the subjective estimation of the passage of time.

Figure 1 shows the effects of illuminating the subject's environment with light of an intensity which was varied at random with respect to time. Similarly Figure 2 shows the effect of providing sound, the intensity and frequency of which was randomly varied with respect to time. 


\section{DISCUSSION}

The purpose of the experiments that we have descrioed was to test a specific hypothesis concerning the mechanism by which human subjects estimate short time intervals of the order of $15 \mathrm{sec}$. We gave our reasons in the introduction to this paper for suspecting that time intervals of this magnitude were determined by the amount of sensory information reaching the central nervous system in unit time. Thus we supposed that a subject asked to estimate a 15 sec. period nould complete this period when an appropriate number of sensory events had accumulated. An analogous mechanism would be the performance of an electronic (or mechanical) digital scaling unit arranged to provide a signal when a pre-set count of ingoing information had been attained. In this situation any factor which would block every second signal at the input, would clearly cause an Iverage delay of the output signal of 100 per cent. Fortunately it is possible to postulate and to test a series of supposed functions of the nervous system without ipecifying the precise neural mechanisms by which these functions are achieved. U'e believe that our results support this hypothesis.

The number of subjects examined in theser periments was very small. Nevertheless, they all showed significant increases in the majority of sensory thresholds that we tested. We have measured responses which are closely related to the sensory thresholds of hearing, warmth, superficial pain, brightness discrimination, touch and proprioception. The inhalation of 25 per cent nitrous oxide appears to raise the threshold for all these modalities of sensation except proprioception. Even in the case of proprioception most of our subjects showed an elevation of threshold, but this was only statistically significant in one subject. The comparatively small effect of nitrous oxide upon proprioception is surprising because "ll our subjects mentioned a feeling of dizziness. Despite this subjective sensation which made the subjects unwilling to stand up, it was in fact possible for our subjects to stand unsupported and to walk along a straight line. We are unable to account for the discrepancy between subjective sensation and the measurements of proprioception; it is possible that although 25 per cent nitrous oxide has little or no effect on proprioception, it has far more effect upon the central restibular system. There are several modalities of sensation which we have made no effort to test, but our results make it clear that with 25 per cent $\mathrm{N}_{2} \mathrm{O}$ in $\mathrm{O}_{2}$ there must be a considerable reduction in the sensory inflow to the central nervous system.

The subjects of Tables I to II were also asked to reproduce $15 \mathrm{sec}$. time intervals (1) and all subjects showed a prolongation of the subjective passage of time when equilibrated with 25 per cent nitrous oxide in oxygen. This increase of time estimate ranged from 20 to 80 per cent of their control values.

Our information, therefore, provides an empirical correlation between the distortion of the subjective time estimate produced by nitrous oxide and the simultaneous elevation of many sensory thresholds.

Our experiments with the effect of environment upon the subjective time estimation ( $\mathrm{p} .117$ ) were undertaken in an attempt to reduce in a different way the amount of information available to the central nervous system. We only 
varied the information presented to the auditory and visual systems, but our results showed clearly that subjective estimates of the passage of time were directly related to this variation. This finding is not surprising since it has often been assumed that "the experience of a certain duration is related to the total amount of experience (sensations, perceptions, cognitive and emotional processes, etc.) which takes place within this time period" (2).

We have suggested above that the human central nervous system estimates time intervals by an integration of experienced sensory events. An alternative mechanism for time estimation, as we have said in the introduction to this paper, might be dependent upon the slow decay of changes set up within the nervous system by the instruction. Thus one might postulate that when a subject is asked to estimate $15 \mathrm{sec}$. "beginning from now" the word "now" sets up instantaneously a change of state which decays slowly with time. When this trace has decayed to a learned fraction of its initial value the subject responds. Such a mechanism would not be inconsistent with the findings of Summerfield and Steinberg (4), who showed that subjects under 30 per cent $\mathrm{N}_{2} \mathrm{O}$ learned less readily and forgot less rapidly than did the same subjects breathing air. They assume in their paper that the primary action of nitrous oxide is to stablize the memory trace, thereby making it more difficult for new information to compete for the storage mechanism. We know of no reason for rejecting such an explanation, but, the results described in this paper make this hypothesis superfluous.

In our opinion the general increase in sensory thresholds which we have described for subjects breathing 25 per cent nitrous oxide provides a sufficient explanation of the three other important changes induced by this anaesthetic. The distortion of time sense, the increase in retention of previously acquired information and the decreased ability to accept for storage newly presented facts, could all be the consequence of the change in sensory thresholds.

\section{SUMMARY}

1. Sensory thresholds have been measured in human subjects while breathing 25 per cent nitrous oxide in oxygen.

2. Nitrous oxide produced a significant and sometimes dramatic increase in the thresholds for touch, skin pain, warmth, vision, and hearing.

3. Elevations in proprioceptive thresholds were not significant.

4. It is suggested that the general increase in sensory thresholds produced by nitrous oxide is a sufficient explanation of the disturbances of memory and time sense that have been observed with nitrous oxide inhalation.

\section{ACKNOWLEDGMENT}

Part of this work was supported by funds allocated to one of us (B. D. B.) by the National Research Council of Canada, to whom we should like to express our thanks. 


\section{RÉSIMÉ}

Dans une publication antérieure, nous avons démontré que des sujets respirant un mélange de $20 \%$ de protoxide d'azote et d'oxygène faisaient des évaluations de périodes de 15 secondes environ deux fois plus longues que celles qu'ils né font lorsqu'ils respirent de l'air. On pourrait présumer que l'évaluation d'une période de temps dépend de la vitesse de décalage de certains changements centraux relativement difficiles à faire et qui sont à leur maxinıum lorsque la durée est brève. Alternativement, l'évaluation subjective d'une période de temps dépend de l'intégration d'un nombre d'événements dont on se souvient. Ainsi un individu à qui on demande d'évaluer ou de mesurer une période de 15 secondes ne pourra le faire seulement quand il aura accumulé un nombre connu d'événements sensoriels dont il se souvient. Le deuxième concept de l'évaluation d'une période de temps supposerait que le protoxide d'azote inhalé entraînerait une augmentation des évaluations subjectives des périodes de temps en produisant un ralentissement dans l'accumulation des événements dans la mémoire. Cela supposerait que le principal effet du protoxide d'azote inhalé serait d'interrompre une certaine partie des trajets nerveux à partir des terminaisons nerveuses jusqu'au mécanisme d'emmagasinage et aussi de réduire les renseignements disponibles pour l'emmagasinage. Bien que l'action du protoxide d'azote sur la réponse à la douleur soit bien connue, on possède peu de renseignements sur l'effet d'une anesthésie générale légère sur les autres modalités sensorielles. C'est pour ces raisons que nous avons étudié les effets de l'inhalation de protoxide d'azote sur un certain nombre d'autres seuils sensoriels.

Tous les sujets observés ont manifesté une augmentátion évidente de la plupart des seuils sensoriels que nous avons étudiés. L'inhalation de $25 \%$ de protoxide d'azote semble élever le seuil pour toutes les modalités de sensations à l'exception de la proprioception. C'est ainsi qu'il existe une corrélation empirique entre la distorsion des estimations subjectives de périodes de temps par l'inhalation de protoxide d'azote et l'élévation simultanée de plusieurs seuils șensoriels. Nous avons modifié les renseignements offerts aux systèmes auditif et visuel chez des sujets qui n'étaient, pas soumis à des inhalations de protoxide d'azote et les résultats démontrent clairement que les évaluations subjectives du temps qui passe étaient en rapport direct avec cette variation. Cela avait pour but d'essayer de réduire d'une autre façon la quantité de renseignements à la disposition du système nerveux central.

La perturbation du sens de la mesure du temps, l'augmentation de l'emmagasinage des renseignements acquis antérieurement et la diminution de l'aptitude à accepter pour emmagasinage des faits présentés récemment, choses qui surviennent chez ceux qui inhalent de faibles concentrations de protoxide d'azote, tout cela ne pourrait être que la conséquence d'un changement des seuils sensoriels.

\section{REFERENCES}

1. Robson, J. G., Burns, B. Delisle, \& Welt, P. J. L. The Effect of Inhaling Dilute Nitrous Oxide upon Recent Memory and Time Estimation. Can. Anaes. Soc. J. 7: 399 (1960).

2. Frankenhaeuser, Marianne. Estimation of Time. Stockholm: Almquist and Wiksell (1959). 
3. Hoagland, H. The physiological Control of Judgements of Duration: Evidence for a Chemical Clock. J. Gen. Psychol. 9: 267 (1933).

4. Summerfield, A., \& Steinberg, Hannaf. Red|ıcing Interference in Forgetting. Quart. J. Exper. Psychol. 9: 146 (1957).

5. Janes, W. Principles of Psychology, I. London: Macmillan (1890).

6. Thomson, R., \& Bryant, J. H. Memory as Affected by Activity of the Relevant Receptor. Psychol. Reports 1: 393 (1955).

7. Goodman, L. S., \& Grluan, A. The Pharmacological Basis of Therapeutics. New York: Macmillan (1955).

8. Butler, T. C. The Theories of General Anaesthesia. Pharmacol. Rev. 2: 121 (1950). 